\title{
Is Financial Analysis Doomed? The Birth of
}

\section{"Reactive Valuation" Analysis}

\author{
Paul A. Griffin ${ }^{1} \&$ Mohammedi Padaria ${ }^{1}$ \\ ${ }^{1}$ Graduate School of Management, University of California, Davis, CA USA \\ Correspondence: Paul A. Griffin, Graduate School of Management, University of California, Davis, CA 95616 USA \\ Tel: 1-530-752-7372.
}

Received: June 14, 2017

Accepted: July 10, 2017

Online Published: July 16, 2017

doi:10.5430/afr.v6n3p39

URL: https://doi.org/10.5430/afr.v6n3p39

\begin{abstract}
The purpose of this paper is to examine how firms' information landscape has changed in recent years and why this could be problematic for those engaged in financial analysis and equity valuation. Our central contention is that two main forces of change - lower information costs and faster information processing - have completely disrupted the traditional concept of financial analysis. In response to this disruption, financial analysis will now increasingly take the form of "reactive valuation." In addition to examining our main contention, we introduce a new term into the literature, called "reactive valuation," which we define as the ultra short-term valuation of an equity, lasting from a few seconds to a few hours, based on information primarily published through social media channels. It may be later corroborated by factually based information or remain unsubstantiated. It may or may not be from an authoritative source. It also may not relate clearly or directly to the valuation of the underlying asset. However, based mostly on the tools of artificial intelligence and natural language processing, "reactive valuation" will invariably provide an opportunity for statistical arbitrage during the short time it takes for the market to digest the information. Financial analysts who survive these two forces of change will have detailed knowledge of this new form of financial analysis.
\end{abstract}

Keywords: Financial analysis, Reactive valuation, Artificial intelligence, Natural language processing

JEL Classification: G14, G24, G32.

\section{Introduction}

The notion of traditional stock financial analysis with its humble beginnings in the pioneering work of Graham \& Dodd (1934) has all but been swept away by the inexorable forces of change cast upon it by robots, Big Data, and artificial intelligence. The financial world is now cluttered with Twitter posts, instant media blogs, direct regulator feeds, and "robo" news reports. These communications have not only become an integral part of our social lexicon but, also, they have become a part of the financial lexicon. Traditional valuation frameworks based on the capital asset pricing model (CAPM) - the bedrock of traditional financial valuation - moreover, may be no match for the speed at which information is generated and impacts equity values. Future cash flows and systematic beta risk, while they may explain some portion of firm value, are increasingly being sidelined by a barrage of social media information flowing 24-7 in the financial marketplace from every conceivable source.

As the main purpose of this paper, we examine how firms' information landscape has changed and what this implies for financial analysis and equity valuation. Our concern is that these changes are transforming an entire field of analysts and advisors who serve the trillion-dollar asset management industry. This is important because asset management is arguably the largest single industry in modern society (Golub, Glattfelder, and Olsen, 2017). Our study of the recent literature, which identifies the key factors at play, concludes that financial analysis as we know it is doomed (defined below as an economic concept). While it has evolved through the ages, today's changes are disruptive and transformative, mostly due to the use of high speed trading at lower cost and algorithmic asset management using Big Data analytics. These two forces of change mean that information is consumed and processed at a pace never seen before. (Note 1)

Relatedly, it is imperative to understand the efficient market hypothesis in the context of this new age of rapid trading and information flow (Asness \& Liew, 2014). This leads us to define a new concept of valuation analysis. We call this "reactive valuation." We introduce this term to the finance literature because valuation analysis in the 
future will depend almost entirely on how we react in real time to the continuous feed of electronic information disclosed in firms' financial and regulatory filings as well as on Twitter and other social media feeds in response to those filings. Should those in the field of financial analysis and valuation not address the implications of high speed trading and algorithmic asset management, others with superior knowledge and skill will emerge, possibly reflecting a "gale of creative destruction," the term used by Joseph Schumpeter in Capitalism, Socialism, and Society (1942, republished in 2013) to describe the effects of disruption and transformation on economic innovation and the business cycle. It is in this Schumpeterian sense, that we advance the idea that the field of financial analysis and valuation as we know it is doomed.

Our paper proceeds as follows. Section 2 discusses the two key forces of change in the financial analysis industry, namely, the lower cost of information infrastructure and the increased speed of information processing. Section 3 assesses how high frequency trading (HFT) and high frequency information impact equity valuation analysis. Section 4 examines the role of Big Data analytics, especially how natural language processing (NPL) and artificial intelligence (AI) are reshaping the landscape (Fisher, Garnsey, and Hughes, 2016). Section 5 then asks whether financial analysts might in part have exacerbated these changes. Section 6 discusses the implications for corporate disclosure. Lastly, based on the preceding sections, we motivate our idea for a new term to describe financial analysis - called "reactive valuation." We define and discuss this new term in Section 7. Section 8 concludes.

\section{Two Inexorable Forces of Change}

The work of financial analysts is fast changing for at least two key reasons. First, the cost of information infrastructure for financial analysis has dropped; so radically that media companies with computer algorithms can now produce instantaneous stock reports with the same look and feel of an analyst report at a fraction of the cost of a human. (Note 2) These effects are widespread and extend to the biggest players in the industry. In early 2017, BlackRock, the world's largest asset manager, shifted much of its approximately $\$ 5$ trillion portfolio (Note 3 ) into lower cost passive funds, where robots use AI and NPL to update asset portfolios in real time to ensure replication of the appropriate index. Relatedly, Calpers, the largest defined benefit pension fund in the United States, (Note 4) recently indicated that it will drop one half of its external investment managers, whose higher labor costs drag down the net return on pension fund assets, which then forces higher contributions on employees to make good on the pension promise. (Note 5) Thus, for financial analysts, their employment as Graham and Dodd stock advisors wanes. Financial robots using AI and NPL are on the ascendency.

A second inexorable force of change relates to information processing speed, which like Moore's Law, has grown exponentially. Software engineers now measure processing speed in nanoseconds (1 millionth of a second). This is staggering, as at this speed the computer crunches numbers faster than a human brain can think of a single word. That takes around 50-80 milliseconds, slow in nanosecond time. Also, with blockchain computing technology (also known as distributed ledger technology), (Note 6) brokers and other institutions can manage order flow more efficiently and balance their ledgers virtually in real time and with high data security. This reduces trading risk because it shortens settlement time and narrows bid-ask margins. Nano-second speed makes it all but impossible for a Graham and Dodd analyst to compete on an even playing field in reacting to new information.

\section{The Rise of HFT}

One result of speedier and less costly information flow has been a dramatic increase in high frequency trading (HFT). By most accounts, HFT now constitutes more than 50 percent of daily trading volume on the U.S. stock exchanges (Aldridge \& Krawciw, 2017) and about 40 percent of European equity markets (Miller \& Shorter, 2016). It is also not just about equity markets, however. According to the CFTC, in 2012-2014, HFT accounted for 67 percent of 10-year Treasuries, 64 percent of Eurodollar futures, 50 percent of metal and energy futures, and 40 percent of agricultural derivative instruments. (Note 7)

The idea behind equity HFT is to make money in trading over very short intervals (in micro- or nano-seconds) by exploiting differences in buy and sell stock quotes (De Jong \& Nijman, 1997; Carrion, 2013; Menkveld, 2013; Brogaard, Hendershott, and Riordan, 2014). HFT traders use five main methods to make money: by (1) placing market making limit orders just outside the quoted bid-ask spread, (2) capturing liquidity rebates by through additional market liquidity from more trading, (3) exploiting momentary price differences for the same stock across multiple exchanges, (4) trying to fool other HFT traders to move prices outside the bid-ask spread, and (5) using information faster through preferential access to public data feeds.

In 2009, shortly after the global financial crisis, HFT was in its heyday, with the industry reporting 2009 estimated world-wide revenues of $\$ 7.2$ billion, as it benefited from high asset price volatility and wide trading spreads. (Note 8 ) 
Now, though, with thinner spreads and lower asset market volatility, HFT is in a bind. Industry revenue last year (2006) shrunk to $\$ 1.1$ billion, and the market capitalization of the world's largest publicly-traded HFT firm, Virtu Financial, is down 23 percent since its IPO in 2005 versus the DJIA, which is up 20 percent for the same period (data as of July $5^{\text {th }}, 2017$ ).

In addition, for HFT, the cost of preferential data is up; the life of a successful trading strategy is down; and structural flaws in HFT trading platforms are harder to find, often quickly corrected by the regulators. For example, as noted by Rogers, Skinner, and Zechman (2017), the SEC recently agreed to eliminate the few-second timing delay between subscribers who receive an early Edgar posting (via the Public Dissemination Service) and those who rely on a posting to the Edgar website. The speed of light and blockchain technology are also imposing physical limits on HFT traders' ability to execute trades at the global level. While traders would like information to flow as fast as possible, data cannot flow and settlements cannot occur any faster than light itself.

Finally, there is the possibility of the HFT industry cannibalizing itself through the use of predatory algorithms that constantly "ping" the market until they find trades meeting their desired price and liquidity specifications. By finding more innovative ways to trade either against each other or against the larger market, HFT traders are reducing industry profits by their own actions.

\section{Big Data Analytics and Social Media Feeds}

HFT may not present an immediate or existential threat to financial analysis, however, because the main drivers of HFT relate more to order flow and spreads as precursors of price discovery. Still, other forms of high-speed financial analysis are disrupting and transforming the marketplace. Firms like Neokami and Sentient now offer trading platforms using Big Data analytics that not only cover unusual order flow but, also, company reports, conference calls, and the sentiment and mood analysis of social media messages (Barberis, Shleifer, and Vishny, 1998; Brown \& Cliff, 2004; Tetlock, 2007; Antweiler \& Frank, 2004; Wurgler, 2007; Zhang, Fuehres, and Gloor, 2011; Kleinnijenhuis, Schultz, Oegema, and Van Atteveldt, 2013; Lee, Hutton, and Shu, 2015; Ranco, Aleksovski, Caldarelli, Grčar, and Mozetič, 2015). "We can analyze millions of variables within seconds and create a customized predictive model for any stock," says Ozel Christo, founder and CEO of Neokami. (Note 9) Some newer companies specialize solely in social media information. For example, Social Market Analytics (socialmarketanalytics.com) calculates a series of sentiment scores (S-Factor) at one-minute frequencies for more than 4,000 individual stocks. These data are then used to create a portfolio of the 25 highest S-Factor stocks within the universe of large CBOE stocks.

One popular example of the promise of Big Data analytics relates to the analysis of Twitter feeds. This has created a substantial and growing literature (Brown, 2012), wherein many academics and professionals claim an ability to predict future movements in stock indexes and individual stock prices based on the sentiment of social media messages. (Note 10) The basic model is disarmingly simple, however. With optimistic messages, one predicts higher future stock prices, and with pessimistic messages one predicts lower future stock prices.

Despite the promise, the key question remains whether they work in practice given that the researchers can only create and test their algorithms on historical data. Interestingly, when put to work to make real money, the most well known Twitter feed model of Bollen, Mao, and Zeng (2011) failed spectacularly. Based on that model, the Derwent Capital Markets Absolute Return Fund closed down after operating for only a few months. A similar fund in the United States, the Crowd Invest Wisdom EFT, based on the principle of allocating stocks according to the sentiment of the "crowd," also had a short life, opening in April 2016 and closing in September 2016. Still, other funds based on sentiment claim financial success, such as the Social Market Analytics' CBOE-SMA Large Cap fund, although this particular fund began only quite recently, in 2014. (Note 11) But given any random sample of social media funds, one would expect some to succeed as predictors for short periods by chance even if stock movements were entirely random. (Note 12)

Lower information cost for public investors from Big Data analytics also hurts institutional investors - the employers of financial analysts - by eliminating a potential source of profit through trading with outsiders. Regulatory initiatives such as the 2009 SEC requirement for firms to file XBRL (eXtensible Business Reporting Language) financial statements have also reduced information processing costs for public investors, as firms' financial statements are now immediately machine-readable for entire populations of registrants. XBRL financial statements also use standardized taxonomies, which allow for instantaneous apples-to-apples comparisons across firms that previously would have required human intervention by financial analysts to generate consistent data. Griffin, Hong, Kim, and Lim (2016) show that the average credit spreads of U.S. credit default swaps dropped by 103-137 basis points as a result of this regulatory effort. 


\section{Sewing the Seeds of Their Demise}

Financial analysts may have also helped sew the seeds of their own demise by acting in ways that defy the logic of well-publicized trading strategies. Illogical as this may seem, a growing literature finds that some analysts' recommendations and price targets actually run counter to the implications of well-documented models of ways to detect under- or overpriced equities, also known as "pricing anomalies." According to Engelberg, McLean, and Pontiff (2017), who study over 90 pricing anomalies, analysts forecast higher future prices when the anomaly indicates a sell; and when the anomaly indicates a buy, analysts forecast lower future prices. Logic would indicate the opposite; that is, if the signal were a sell (buy), then one would expect lower (higher) future prices. This result also extends to the contradictory actions of institutional investors. Edelen, Ince, and Kadlec (2016) show that institutional investors on average tend to buy overvalued stocks when the pricing anomaly indicates a sell and tend to sell undervalued stocks when the pricing anomaly indicates a buy. They trace the contradiction to institutions' use of short holding periods compared to one year or longer periods used to test the success of an anomaly. (Note 13)

A similar narrative (of misanalysis) is echoed in work regarding the pricing of fossil fuel reserves disclosed on energy company balance sheets in light of a fixed carbon budget (the realization that only so much more carbon can be burned to avoid excessive global warming). Griffin, Jaffe, Lont, and Dominguez-Faus (2015) show that the stock market adjusted to the notion of a fixed carbon budget in 2009, when the research was first published and discussed in the media. The idea of a fixed carbon budget was also discussed in 2001 in the IPCC's Third Assessment report. (Note 14) In 2013, however, financial analysts at several top firms (e.g., HSBC Global) and thought leaders such as Al Gore and Mark Carney (Note 15) warned of an impending asset bubble that would burst and drive down oil and gas stock prices despite the earlier published evidence of a carbon budget. Four years later, this bubble has yet occur. Nevertheless, some investors and stock funds, possibly in a rush to divest, would have sold Big-oil stocks in response to the analysts' recommendations that in hindsight turned out as incorrect.

One implication of this contrarian behavior is that some financial analysts may actually be contributing to market volatility by unwittingly introducing additional risk into the market through their misdiagnosis of the pricing anomalies (that glean insights from public information). This is a social disservice. What is more, should investors whose asset managers act on the recommendations of analysts realize that they are actually paying for their analysts' mistakes by accepting lower realized returns, this may further accelerate their demise. Consistent with this view, a recent report by S\&P-Dow Jones finds that over the past 15 years more than 90 percent of U.S actively managed investment funds underperformed their passive index counterparts. (Note 16) No wonder institutions and others are shifting more assets to passive index funds managed in part by computer algorithms to track the relevant index.

Despite analysts' contrarian behavior, the search for positive alpha (stock or portfolio return in excess of risk-adjusted return) continues at a fast pace. This pace, according to BlackRock, (Note 17) is also accelerating in line with the expansion of machine-readable data and the ability of algorithms to identify predictive patterns in the data that survive out-of-sample testing. These predictive patterns increasingly rely on access to alternative and unstructured data sets, which is another developing area of expertise for today's financial analysts. These include the use of satellite imagery (e.g., the number of cars in a retailer's parking lot), behavioral information from smart phones and mobile devices, information from FOIA (Freedom of Information Act 5 U.S.C. § 552; FOIA Improvement Act of 2016, Public Law No. 114-185) requests, and cost inputs from non-corporate sources, such tax assessments and energy usage from public records. (Note 18)

Another pressure about to hit Europe in 2018, and potentially affect U.S. financial analysts in years thereafter, is the European Union's MiFID II unbundling regulation. (Note 19) Among the many aspects of asset market regulation, MiFID II requires disclosure to investors of all costs and charges paid that affect the net amount paid to them as return. Because these disclosures will identify potentially excessive fees paid for investment research, the anticipatory reaction of many institutions has been to adopt lower cost passive and index-based investment strategies. The need for human input by financial analysts is, thus, further reduced by the likely effects of this regulation-induced shift in asset management strategies.

\section{Company Disclosure Policies}

The changing role of financial analysis also has profound implications for company disclosure. Since the theory and evidence on the stock market effects of voluntary disclosure mostly concludes that managers develop policies in the best interests of shareholders, net of the costs of disclosure (Diamond \& Verrecchia, 1991; Lambert, Leuz, and Verrecchia, 2007; Healy \& Palepu, 2001; Beyer, Cohen, Lys, and Walther, 2010) that in turn increase firm value, one might conclude that companies should engage more in social media disclosure. However, if the large flow of social media information were to influence investors' understanding of firm performance, additional company 
voluntary disclosure could have countervailing effects, which could increase asset risk. This would occur, for example, if managers' reports to shareholders (e.g., in conference calls, discussions in SEC filings) were to reveal subconsciously sentiment information to investors or create unnecessary controversy, driving share prices in unintended directions. Companies must, therefore, acquire the tools to patrol the universe of social media information about their products, services, and reputation and respond when necessary to protect firm value. A financial analyst, however, trained in the techniques of Graham and Dodd may not understand these new tools.

\section{Birth of "Reactive Valuation" Analysis}

What does the new world of financial analysis look like? First, financial analysts will increasingly engage in "reactive valuation." We define this new term as follows: "Reactive valuation" is the ultra short-term valuation of an equity, lasting from a few seconds to a few hours, based on information published through one of the social media channels. It may later be corroborated by factually based information or remain unsubstantiated. It may or may not be from an authoritative source. It also may not relate clearly or directly to the valuation of the underlying asset. However, it will invariably provide an opportunity for statistical arbitrage during the short time it takes for the market to understand the information. The specifics of the arbitrage, though, will depend on interpreting the reactive valuation correctly, in particular, determining the size, direction, and duration of any mispricing, and whether that mispricing occurs because of an overlooked risk factor or from short-term market frictions or anomalies.

Three recent examples illustrate this new concept of reactive valuation.

First, consider the scenario of Hewlett-Packard's stock. On August $18^{\text {th }}, 2011$ at 12:08 pm, Bloomberg flashed the news "Hewlett-Packard said to spin off PC Business." Almost instantaneously - 4 seconds later according to Gourley (2012) - the market reacted to that news and jumped approximately 14 percent. This information was from a reliable source, namely Bloomberg; it was also materially significant. But before the analyst and regular investors had finished reading the news, the market had already reacted, mainly through algorithms consuming the news and projecting its impact. Financial analysts and investors did not have time to calculate new cash flow projections, a new beta risk versus the market, and the financial impact of the divestiture, and nor did or could they have come up with a new market value for the likely new HP entity. They simply reacted to the news.

Second, on April $23^{\text {rd }}, 2013$ at 1:07 pm, the Associated Press tweeted that President Obama had been injured in an explosion at the White House. Although the stock market quickly recovered to pre-tweet prices, within three minutes, the S\&P 500 Index (and shares indexed thereto) had dropped by one percent or by approximately $\$ 137$ billion. This created a significant opportunity for arbitrage due to the selling by HFTs in response to trigger words such as "explosion" and "injury" linked to the president. On the other side of the trade, however, were HFT buyers, as it quickly became clear that the tweet was not written in AP's normal style, which to some meant that AP's computers had probably been hacked with false information. Still the market moved quickly, creating the potential for arbitrage profits on both sides of the trade for those able to respond within the few minutes of the price disequilibrium.

Third, consider the situation of Lockheed Martin on December $12^{\text {th }}$, 2016. At 8:30 am on December $12^{\text {th }} 2016$, then candidate Donald Trump tweeted ... "The F-35 program is out of control. Billions of dollars can and will be saved on military (and other) purchases after January $20^{\text {th }}$." After the tweet, Lockheed Martin's market value dropped by US\$4 billion. Along with Lockheed, shares of defense stocks of Boeing and General Dynamics dipped 0.72 percent and 2.87 percent, respectively. There was no release of materially significant information; no change in active contracts; and no initiation of review or change of a signed agreement. Nonetheless, the equity markets reacted and created a statistical arbitrage. Financially, there was no change in the fundamentals of Lockheed Martin that would have required an updated valuation of the equity or the underlying asset. Once the market was able to absorb and analyze the information, the equity bounced back to its original value. (open $\$ 253.7$; close $\$ 253.11$; low $\$ 245.5$ ). The volume of shares traded on December $12^{\text {th }} 2016$ was 7 million vs. an average of 1.27 million.

As a result of reaction valuation, there will be fewer analysts of the Graham and Dodd kind. The surviving minority, however, will be well versed in the art and science of cash flow analysis and how it relates to reactive valuation. No matter how many billions of Twitter messages might pertain to firms' activities, such as S-scores and the like, those messages must still be organized coherently and relate to the long-term market value of the firm in terms of assessments of the ability of the firm to generate future cash and the future risks to which those future cash flows will be exposed. It does not really matter how thoroughly Big Data models based on correlations are back-tested in out-of-sample settings, those correlations must eventually explain the fundamentals of valuation based on risk-adjusted future firm cash flows. Some of those asset value risks will also be more distant than before, such as changes in firms' operating and investment activities from climate change risk, which can require 50-year projections. Those financial analysts who survive the forces of changes will also have detailed knowledge of the 
response of stock prices to market frictions and asset pricing anomalies, particularly those that take longer than others to be understood and operationalized by asset managers. (Note 20) As a result, the totality of information reflected in stock prices will even more quickly reflect asset fundamentals with the minimum of bias in accordance with the efficient market hypothesis.

\section{Conclusion}

The flow of low cost information for stock pricing will grow at a rate faster than we can imagine. Unstructured, uncorroborated (ad hoc) news items will travel more quickly across investors than their ability to validate them. Financial markets are inextricably linked to this new world of massive and rapid information flow. "Reactive valuation" will be the new norm for financial valuation analysis. Markets are more efficient than ever (Malkiel, 2005), yet trading algorithms used by HFT and Big Data analytics continue to create endless forms of statistical arbitrage. If financial analysts can update their valuations to include correctly the predictive impacts of ad hoc news and pricing anomalies into the equity prices, then we have the opportunity to fold reactive valuation into the standard cash flow valuation methodologies, thus, leading to a way to manage the chaos. Even so, we will never be able to rid ourselves of the chaos completely.

Our paper, thus, contributes to the literature in finance by highlighting the increased use of information from social media and other electronic data sets for asset valuation and the disruptive effects of the two major forces of change affecting the analysis of that information - of higher information processing speeds and lower information processing costs. From this disruption, we observe that a new concept of financial analysis and valuation has emerged, which we define as "reactive valuation." Those individuals who master the tools of reactive valuation analysis will greatly transform the field of financial analysis and valuation. Our prediction, that lower processing costs and faster information processing will generate significant changes in the asset management industry, is not without its limitations, however, mainly for two reasons. We do not cover the entire array of changes in the field of financial analysis and valuation as a result of Big Data, AI, and HFT; and that threats from newer, smaller firms may incentivize the larger financial institutions to evolve their technologies from within, which may make the transformational changes less disruptive.

An interesting challenge for future research would be to track one key implication of our study: to document the changes (and rates of change) in the field of financial analysis and valuation conditional on the full force of the transformational factors we identify. What are the employment trends at the major investment institutions? What are the backgrounds and experience of their more recent hires? What has changed in the examination requirements for qualification as a Chartered Financial Analyst? How successful in practice are algorithmic trading platforms versus models based mostly on human input? What aspects of financial analysis do the algorithmic platforms best capture? What kinds of investment firms (or consortia of firms) are the first and last to adopt technologies to exploit the benefits of disruptive change? When it comes to models of investment choice based on social media sentiment, or stock market anomalies that general positive alpha, what is the long-run success of those models for asset fund management? Given that asset managers worldwide have sway over portfolios whose total economic value has been estimated to exceed \$64 trillion (McKinsey and Company, 2015), these are all relevant and important questions and a logical next stage for future research.

\section{References}

Aldridge, I., \& Krawciw, S. (2017). Real-time risk: What investors should know about fintech, high frequency trading, and flash crashes. Hoboken: Wiley. https://doi.org/10.1002/9781119319030

Antweiler, W., \& Frank, M. Z. (2004). Is all that talk just noise? The information content of Internet stock message boards. The Journal of Finance, 59(3), 1259-1294. https://doi.org/10.1111/j.1540-6261.2004.00662.x

Asness, C., \& Liew, J. (2014). The great divide over market efficiency. Institutional Investor.

Baker, M., \& Wurgler, J. (2007). Investor sentiment in the stock market. The Journal of Economic Perspectives, 2l(2), 129-151. https://doi.org/10.3386/w13189

Barberis, N., Shleifer, A., \& Vishny, R. (1998). A model of investor sentiment. Journal of Financial Economics, 49(3), 307-343. https://doi.org/10.1016/S0304-405X(98)00027-0

Beyer, A., Cohen, D. A., Lys, T. Z., \& Walther, B. R. (2010). The financial reporting environment: Review of the recent literature. Journal of Accounting and Economics, 50(2-3), 296-343. https://doi.org/10.1016/j.jacceco.2010.10.003 
Bollen, J., Mao, H., \& Zeng, X. (2011). Twitter mood predicts the stock market. Journal of Computational Science, 2(1), 1-8. https://doi.org/10.1016/j.jocs.2010.12.007

Brogaard, J., Hendershott, T., \& Riordan, R. (2014). High-frequency trading and price discovery. Review of Financial Studies, 27(8), 2267-2306. https://doi.org/10.1093/rfs/hhu032

Brown, E. D. (2012). Will Twitter make you a better investor? a look at sentiment, user reputation and their effect on the stock market. Proc. of SAIS.

Brown, G. W., \& Cliff, M. T. (2004). Investor sentiment and the near-term stock market. Journal of Empirical Finance, 11(1), 1-27. https://doi.org/10.1016/j.jempfin.2002.12.001

Carrion, A. (2013). Very fast money: High-frequency trading on the NASDAQ. Journal of Financial Markets, 16(4), 680-711. https://doi.org/10.1016/j.finmar.2013.06.005

Cederburg, S., \& O'Doherty, M. S. (2015). Asset-pricing anomalies at the firm level. Journal of Econometrics, 186(1), 113-128. https://doi.org/10.1016/j.jeconom.2014.06.004

De Jong, F., \& Nijman, T. (1997). High frequency analysis of lead-lag relationships between financial markets. Journal of Empirical Finance, 4(2-3), 259-277. https://doi.org/10.1016/S0927-5398(97)00009-1

Diamond, D. W., \& Verrecchia, R. E. (1991). Disclosure, Liquidity, and the Cost of Capital. The Journal of Finance, 46(4), 1325-1359. https://doi.org/10.2307/2328861

Edelen, R. M., Ince, O. S., \& Kadlec, G. B. (2016). Institutional investors and stock return anomalies. Journal of Financial Economics, 119(3), 472-488. https://doi.org/10.1016/j.jfineco.2016.01.002

Engelberg, J., McLean, R. D., \& Pontiff, J. (2017). Analysts and anomalies. Available at ssrn.com/abstract=2939174. SSRN eLibrary. https://doi.org/10.2139/ssrn.2939174

Fisher, I. E., Garnsey, M. R., \& Hughes, M. E. (2016). Natural language processing in accounting, auditing and finance: A synthesis of the literature with a roadmap for future research. Intelligent Systems in Accounting, Finance and Management, 23(3), 157-214. https://doi.org/10.1002/isaf.1386

Golub, A., Glattfelder, J., \& Olsen, R. B. (2017). The alpha engine: Designing an automated trading algorithm, high performance computing in finance. Chapman \& Hall/CRC Series in Mathematical Finance, April.

Gourley, S. (2012). High frequency trading and the new algorithmic ecosystem, August 9. Available at seangourley.com/2012/08/high-frequency-trading-and-the-new-algorithmic-ecosystem/.

Graham, B., and David Dodd. (1934). Security analysis, Whittlesey House, McGraw-Hill Book Co., ISBN 0-07-144820-9 (2005 edition).

Griffin, P., Hong, H., Kim, J. B., \& Lim, J. (2016). The SEC's XBRL mandate and credit risk: Evidence on a link between credit default swap pricing and XBRL disclosure. Working paper, Graduate School of Management, University of California.

Griffin, P. A., Jaffe, A. M., Lont, D. H., \& Dominguez-Faus, R. (2015). Science and the stock market: Investors' recognition of unburnable carbon. Energy Economics, 52, Part A, 1-12. https://doi.org/10.1016/j.eneco.2015.08.028

Healy, P. M., \& Palepu, K. G. (2001). Information asymmetry, corporate disclosure, and the capital markets: A review of the empirical disclosure literature. Journal of Accounting and Economics, 31(1), 405-440. https://doi.org/10.1016/S0165-4101(01)00018-0

Kleinnijenhuis, J., Schultz, F., Oegema, D., \& Van Atteveldt, W. (2013). Financial news and market panics in the age of high-frequency sentiment trading algorithms. Journalism, 14(2), 271-291. https://doi.org/10.1177/1464884912468375

Lambert, R., Leuz, C., \& Verrecchia, R. E. (2007). Accounting Information, Disclosure, and the Cost of Capital. Journal of Accounting Research, 45(2), 385-420. https://doi.org/10.1111/j.1475-679X.2007.00238.x

Lee, L. F., Hutton, A. P., \& Shu, S. (2015). The role of social media in the capital market: Evidence from consumer product recalls. Journal of Accounting Research, 53(2), 367-404. https://doi.org/10.1111/1475-679X.12074

Malkiel, B. G. (2005). Reflections on the efficient market hypothesis: 30 years later. Financial Review, 40(1), 1-9. https://doi.org/10.1111/j.0732-8516.2005.00090.x 
McKinsey and Company (2015). The \$64 trillion question: Convergence in asset management, Wealth \& Asset Management, McKinsey and Company, February. http://www.mckinsey.com/industries/private-equity-and-principal-investors/our-insights/the-64-trillion-question

McLean, R. D., \& Pontiff, J. (2016). Does academic research destroy stock return predictability? The Journal of Finance, 71(1), 5-32. https://doi.org/10.1111/jofi.12365

Menkveld, A. J. (2013). High frequency trading and the new market makers. Journal of Financial Markets, 16(4), 712-740. https://doi.org/10.1016/j.finmar.2013.06.006

Miller, R. S., \& Shorter, G. (2016). High frequency trading: Overview of recent developments. Washington: Congressional Research Service.

Ranco, G., Aleksovski, D., Caldarelli, G., Grčar, M., \& Mozetič, I. (2015). The effects of Twitter sentiment on stock price returns. PloS One, 10(9). https://doi.org/10.1371/journal.pone.0138441

Rogers, J. L., Skinner, D. J., \& Zechman, S. L. C. (2017). Run EDGAR run: SEC dissemination in a high-frequency world. Chicago Booth Research Paper No. 14-36; Fama-Miller Working Paper. ssrn.com/ abstract=2513350. January 1. SSRN eLibrary. https://doi.org/10.1111/1475-679x.12167

Schumpeter, J. A. (2013). Capitalism, socialism and democracy: Routledge. (First edition published in 1942 by Harper and Brothers.)

Tetlock, P. C. (2007). Giving content to investor sentiment: The role of media in the stock market. The Journal of Finance, 62(3), 1139-1168. https://doi.org/10.1111/j.1540-6261.2007.01232.x

Zhang, X., Fuehres, H., \& Gloor, P. A. (2011). Predicting stock market indicators through Twitter "I hope it is not as bad as I fear." Procedia-Social and Behavioral Sciences, 26, 55-62. https://doi.org/10.1016/j.sbspro.2011.10.562

\section{Notes}

Note 1. According to www.internetlivestats.com as of July 5th, 2017, there were approximately 3.68 billion Internet users, 1.220 trillion websites, and over the prior 24 hours, 3.8 million new blogs, 504 million tweets, 83 million Tumblr posts, and 3,037,641,850 gigabytes of data flowed through the Internet.

Note 2. The Associated Press uses its the natural language platform Wordsmith (https://automatedinsights.com/) to write more than 4,000 earnings stories every quarter based on raw earnings reports. (Last retrieved July 7, 2017.)

Note 3. 2016 data. Managed assets by the world's top 15 asset managers totaled \$29.5 trillion as of March 2016, of which BlackRock comprised 16\% (www.statista.com/topics/2365/exchange-traded-funds/). (Last retrieved July 7 , 2017.)

Note 4. \$323.6 billion under management as of April 30th, 2017 (www.calpers.ca.gov). (Last retrieved July 7, 2017.)

Note 5. www.wsj.com/articles/calpers-to-cut-external-money-managers-by-half-1433735976. (Last retrieved July 7, 2017.)

Note 6. knowledge.wharton.upenn.edu/article/blockchain-technology-will-disrupt-financial-services-firms/. (Last retrieved July 7, 2017.) www.the-blockchain.com/docs/joint-report-by-jp-morgan-and-oliver-wyman-unlocking-economic-advantage-with-bl ockchain-A-Guide-for-Asset-Managers.pdf (Last retrieved July 7, 2017.)

Note 7. www.cftc.gov/PressRoom/SpeechesTestimony/opamassad-30. (Last retrieved July 7, 2017.)

Note 8. www.wsj.com/articles/high-frequency-traders-fall-on-hard-times-1490092200. (Last retrieved July 7, 2017.)

Note 9. www.cnbc.com/2015/07/09/neokamis-artificial-intelligence-app-wants-to-make-you-a-top-stock-picker.html. (Last retrieved July 7, 2017.)

Note 10. Of 175 articles on NPL in accounting, auditing, and finance published between 1984 and 2014, 52\% have dates in 2010-2014 (Fisher et al. 2016, Appendix D). These data also indicate that since 2000 the number of articles published on NPL has increased on average at $16 \%$ per year.

Note 11. www.hedgeweek.com/2017/01/16/247595/cboe-launches-second-social-media-benchmark-index. (Last retrieved July 7, 2017.) 
Note 12. A model that is optimized for a current market regime may not be robust to market or regime changes and, thus, fail in the longer-term, which may be one reason for the failure of many academic stock market prediction models in practice. On this point, Golub et al. (2017, p. 4) emphasize the need for model parsimony (the use of a limited set of variables) and a common model structure that can represent different market conditions and regimes by only needing to re-estimate the model parameters. See papers.ssrn.com/sol3/papers.cfm?abstract_id=2951348. (Last retrieved July 7, 2017.)

Note 13. Whether the misanalysis of pricing anomalies leads to higher stock volatility remains an open case, however. For example, Cederburg and O'Doherty (2015, p. 115) find that only two anomalies earn excess profits in the post-publication period, and that in those cases the profits relate mainly to relatively illiquid small-cap stocks with high transaction costs.

Note 14. www.ipcc.ch/ipccreports/tar/. (Last retrieved July 7, 2017.)

Note

https://www.theguardian.com/environment/2014/oct/13/mark-carney-fossil-fuel-reserves-burned-carbon-bubble. (Last retrieved July 7, 2017.)

Note 16. www.wsj.com/articles/the-dying-business-of-picking-stocks-1476714749. (Last retrieved July 7, 2017.)

Note 17. "Finding big alpha in big data: The evolution of active investing," BlackRock, July 2015 (Lit. No. INST-BIG-ALPHA-0715R).

Note 18. For example, an income tax assessment might indicate substantial differences between reported and taxable income; and a property tax assessment might indicate substantial differences between reported and taxable property.

Note 19. https://www.esma.europa.eu/ (Last retrieved July 7, 2017.)

Note 20. In a study of 97 asset pricing anomalies, McLean and Pontiff (2016) find that, consistent with bias in academics' initial estimates of alpha, the excess returns after publication from these anomalies decrease significantly for future out-of-sample portfolios when arbitrageurs' subsequently use these anomalies in an effort to earn excess returns net of trading costs. 